\title{
Catalytic Nanoparticles for DMFC and DFAFC: Reaction Rates, Local Densities of States, and Oxygen Shuttling Pathways \\ DE-FG02-99ER14993
}

by Andrzej Wieckowski(co-PI) and Richard Masel (PI), University Of Illinois

\section{Table of Contents}

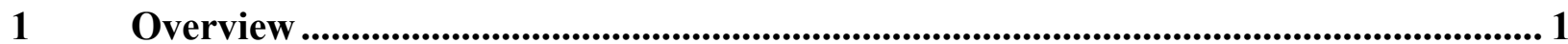

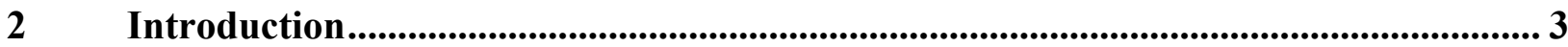

$3 \quad$ Results from DOE Support ........................................................................................... 4

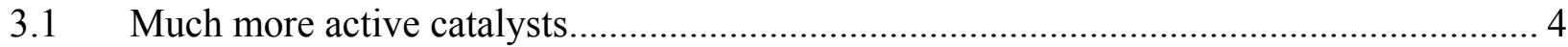

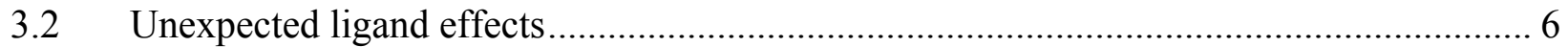

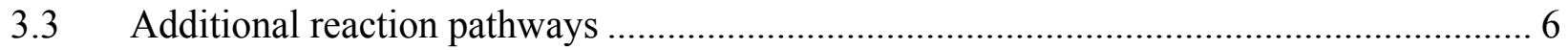

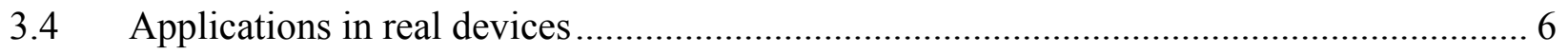

3.5 Anion and Concentration effects ................................................................................ 6

3.6 Publications Supported by Department of Energy grant DE-FG02-99ER14993 …........... 8

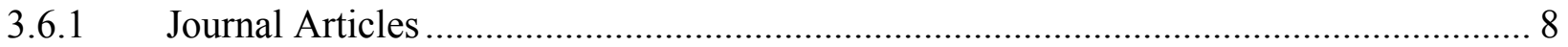

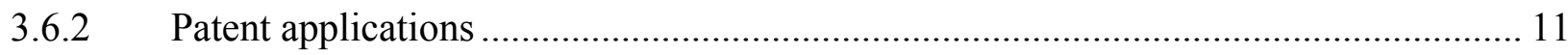

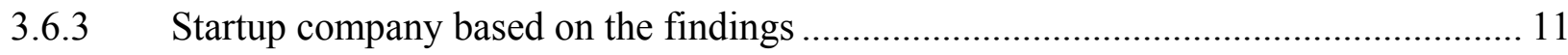

\section{Overview}

The object of this project has been to combine novel synthetic methods to produce much more active anode catalysts for fuel cells, and the use of spectroscopy to develop a molecularlevel understanding of chemical physics principles of the fuel cell catalyst operation. We have made tremendous recent progress as evidenced by our 25 journal articles and 6 patents listed in Section 3.7 page 7. We have developed the most active catalysts for Direct Formic Acid Fuel Cells and discovered a correlation between spectroscopy (Pd 3d binding energy) and performance. We have observed the largest effect of particle size on fuel cell performance found to date where $3 \mathrm{~nm}$ palladium particles give an order of magnitude higher steady state current per exposed metal atom than $6 \mathrm{~nm}$ particles. We discovered a series of as yet unexplained support effects where $\mathrm{Pd}$ on $\mathrm{V}_{2} \mathrm{O}_{5}$ gives an order of magnitude more current than pure palladium. We have verified the results in operating fuel cells and are closing in on the DOE targets[1,2] of anode catalysts for portable fuel cells (costing less than $\$ 1 /$ watt). Table 1 page 2 summarizes where these findings are described in the proposal for the reviewers reference. 
Generally, our approach will be to correlate spectroscopy (XPS, NMR, and STM) to kinetic (CA, CV and VI) measurements as summarized in Error! Reference source not found. page Error! Bookmark not defined. in an attempt to better understand how differences in the particle size and support lead to differences in performance. We already have noticed a correlation between XPS binding energy and activity. We propose expanding this correlation to see if we can explain the effects of particle size and support on performance. We also propose expanding the effort using in situ STM, and EC-NMR to better characterize the changes in the catalysts as we change the support so that we can develop a fundamental understanding for catalyst design.

As a second thrust of the work, we will continue of our efforts to develop novel synthetic methods to prepare electrochemical catalysts. In particular we will extend the spontaneous deposition methodology developed in previous grant cycles [3-8] to the production of metal coated conducting oxide supports so we can turn the $\mathrm{Pd}$ on/metal oxide films that show high activity into practical catalysts.

Table 1 Our key results over the last three years

Much more active catalysts for DFAFC's $-100 \times$ previous ones

Section 3.1 page 4

An unexpected difference between nanoparticles and metal bulk:

Reactivity and BE change

Section 3.1 page 5

An unexpected ligand effect, further enhancing the rate by a factor of 10 . Section 3.2 page 6 Unexpected reaction pathways Section 3.3 page 6

Tests at real fuel cell conditions Section 3.4 page 6 Interesting anion and concentration effects Section 3.5 page 6

New method of nanoparticle catalysts transfer to UHV for XPS study Section 3.6 page 7

Reactivity enhancing heat treatment effect for $\mathrm{Pt} / \mathrm{Ru}$ catalysis for methanol Section 3.6 page 7

Correlations between spectroscopy and performance Section 3.6 page 7 25 publications, 6 patents, and a startup company Section 3.7 page 7 


\section{Introduction}

This is a report for the project "Catalytic Nanoparticles for DMFC and DFAFC: Reaction Rates, Local Densities of States, and Oxygen Shuttling Pathways" by Andrzej Wieckowski and Richard Masel. The work combines in situ electrochemical, spectroscopies (EC-NMR and XPS) and UHV measurements to provide a rational basis for the anode catalyst development for PEM fuel cells. The focus has been on using novel synthetic methods to produce much more active anode catalysts for fuel cells, and the use of spectroscopy to develop a molecularlevel understanding of chemical physics principles of the fuel cell catalyst operation.

A continuing thrust of the work has been the use of spontaneous deposition to produce novel fuel cell catalysts. We start with a metal nanoparticle core and use spontaneous deposition to "decorate" the core with a second metal. This has produced catalysts with unique structure and activity. Ruthenium particles decorated with Pt (Figure 1) are currently one of the most active catalysts for direct methanol fuel cells (DMFC) [4] while palladium decorated with gold shows the highest stability for direct formic acid fuel cells (DFAFC) [8-10]. (The list of references is on page 13).

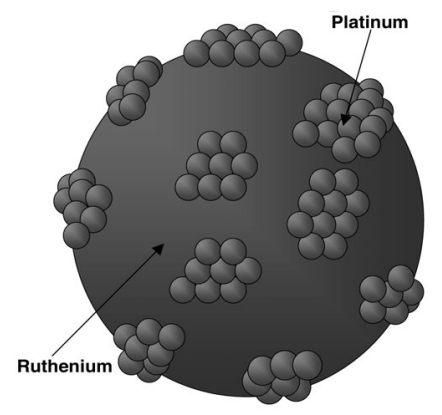

Figure 1 Schematic diagram of a $\mathrm{Ru}$ nanoparticle decorated with Pt atoms.

A second continuing thrust of the work has been to use spectroscopy to better understand how fuel cells function. When we started the project, we predominantly used a combination of UHV and electrochemical measurements to understand the fuel cell performance. As the work has proceeded, while we still rely on the UHV measurements, we are now are concentrating mainly on in situ measurements, such as electrochemical NMR and STM, plus measurements such as XPS where we rapidly transfer samples out of an electrochemical cell for the UHV-XPS assay.

In our work, we have concentrated on anode catalysts portable applications. When we started this work, the anode catalysts for portable electronics cost $\$ 25 /$ watt, while the DOE had set a target of $\$ 1 /$ watt. Thus there was a substantial need to improve the catalytic activity. In the last three years we have spent more time on formic acid fuel cells than on direct methanol fuel cells. Formic acid fuel cells are a new technology originally developed at UIUC, and now being commercialized by Renew Power and Motorola. The advantages of formic acid are:

- Low crossover: about $20 \mathrm{ma} / \mathrm{cm}^{2}$ with 20 M solutions in operating fuel cells. This allows high concentrations to be used within the fuel cell simplifying the design.

- Much higher specific energy densities: over $80 \mathrm{~W} /$ liter in packaged devices. This is the only technology that has exceeded the DOE target of $30 \mathrm{w} / \mathrm{lit}$ for portable electronics. (DMFC is now at 6 $\mathrm{w} / \mathrm{l})$

- Lower catalyst loadings: unlike methanol, formic acid seems to enhance rather than poison the cathode catalyst. In unpublished data we have produced 240 $\mathrm{mW} / \mathrm{cm}^{2}$ at $35 \mathrm{C}$ with only $0.1 \mathrm{mg} / \mathrm{cm}^{2}$ of $\mathrm{Pt} / \mathrm{C}$ on the cathode. This should allow the DOE cost targets to be met.

- Much simplier regulatory situation. There are many regulatory hurdles than need to 
be overcome before fuel cells can be sold to consumers. In particular, consumer electronics that contain class III flamable liquids need to be approved by the International Civil Aviation Organization (ICAO), and get a United Nations (UN) vote to allow an exception to the UN dangerous goods rules for transport. The ICAO vote is at least a year away. Then there is a two year delay to get approval by the UN. Formic acid, being nonflamable does not require UN approval. It does require approval by ICAO.

Given these advantages, particularly the regulatory advantages, it is likely that formic acid fuel cells will be the first to the market in consumer products.

Our DOE supported effort has been to use novel synthetic methods to produce more active catalysts for DMFC and DFAFC's, and to do detailed spectroscopy to understand how and why the catalysts function. In work in the prior grant period, we developed a novel method, spontaneous deposition [3-8] to create new catalysts. We have exploited that method and others in the present grant period, and have also continued developing NMR and XPS to understand how the catalysts function.

\section{Results from DOE Support}

We have 31 papers and patents over the last three years as listed in section 3.7. There is not room here to discuss all of the findings, but it is useful to list the highlights. Our key discoveries over the last three years include:

- Much more active catalysts for DFAFC's $100 \times$ previous ones

- An unexpected difference between nanoparticles and metal bulk: Reactivity and $\mathrm{BE}$ change. A unexpected ligand effect, further enhancing the rate by a factor of 10 .

- Unexpected reaction pathways

- Interesting anion and concentration effects
- New method of nanoparticle catalysts transfer to UHV for XPS study

- Reactivity enhancing heat treatment effect for $\mathrm{Pt} / \mathrm{Ru}$ catalysis for methanol

- Coordinated EC-NMR - reactivity measurements

\subsection{Much more active catalysts}

One key discovery over the last three years was a series of palladium based catalysts for formic acid electrooxidation that are much more active than any catalyst considered previously. This discovery arose out of our attempt to understand why the $\mathrm{Pt} / \mathrm{Pd}$ catalysts first synthesized in our previous grant cycle [3] showed unusual catalytic activity [8]. We did a number of studies [13-15] to understand the differences. We found that $\mathrm{CO}$ formation was inhibited by the addition of palladium; see Figure 2. The CO is normally a poison for the reaction, and so the suppression of the $\mathrm{CO}$ formation pathway by palladium leads to higher steady state catalytic activity.

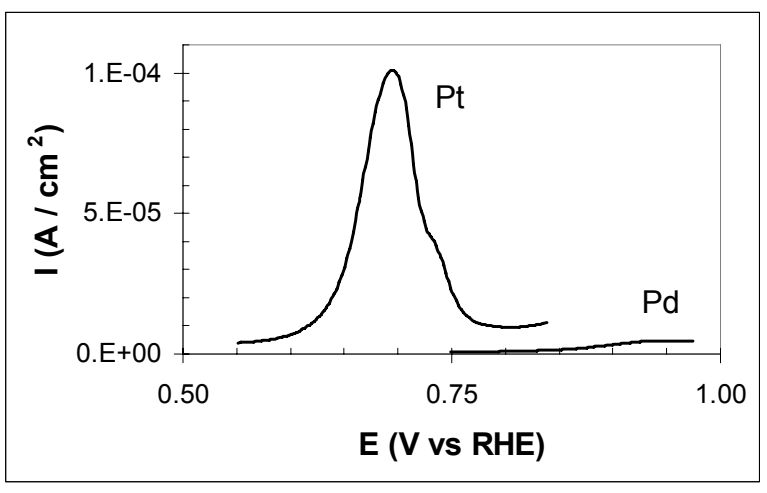

Figure 2 A comparison of the $\mathrm{CO}$ stripping peaks taken after oxidation for 1 hour in $5 \mathrm{M}$ HPLC grade formic acid at $0.3 \mathrm{~V}$ vs RHE [8, 15].

The surprising feature in the data, though was that the catalytic activity increased 
monotonically with the palladium coverage on the platinum surface, up to palladium coverages of 3 monolayers. This suggested that the palladium itself was the active catalyst and the platinum was merely a support.

Previously, Capon and Parsons [16] had compared formic acid electrooxidation on palladium and platinum foils, and found that palladium was less active than platinum, but given these results we decided to reexamine formic acid electrooxidation on palladium again. In particular, Capon and Parsons had only considered palladium foils. We decided to consider palladium particles, and to determine whether small palladium particles, would show unusual activity.

Figure 3 and Figure 4 shows some of the results of this work. We find that palladium nanoparticles are much more active than palladium foils, commercial platinum catalysts or commercial platinum ruthenium catalysts. The foils show some initial activity for formic acid electrooxidation, but they are quickly poisoned due to $\mathrm{CO}$ formation. Surprisingly, the poisoning is suppressed [8-12] on palladium nanoparticles. There is also an interesting effect of particle size, where smaller particles give superior poisoning resistance. At steady state, $3 \mathbf{n m}$ palladium particles are an order of magnitude more active per unit surface area than $6 \mathrm{~nm}$ particles. Clearly, we have found a new, more active class of catalysts for the proposed study, see below.

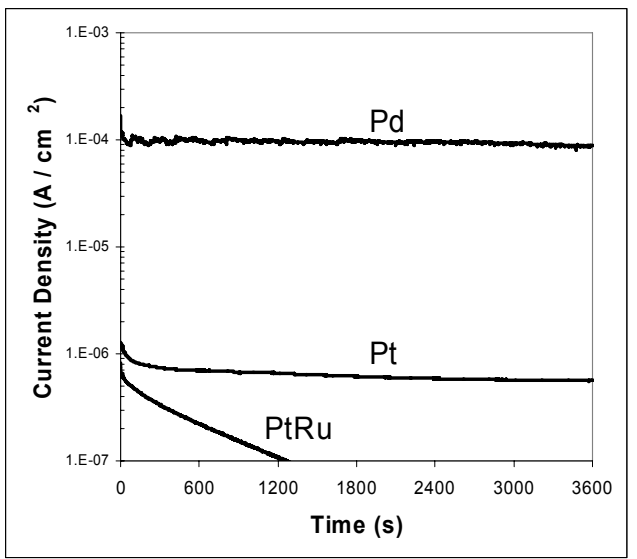

Figure 3 Chronoamperometric data taken during oxidation of formic acid in a solution of $5 \mathrm{M}$ formic acid and $0.1 \mathrm{~N} \mathrm{H}_{2} \mathrm{SO}_{4}$ at $21^{\circ} \mathrm{C}$ at $0.3 \mathrm{~V}$ with respect to RHE. Notice that the palladium catalysts are more than 100 times as active as Johnson Matthey $\mathrm{Pt}$ or $\mathrm{Pt} / \mathrm{Ru}$. [10, 11]

In other work we have run these catalysts for 500 hours. There is some loss of activity due to buildup of impurities in our formic acid stream, but that can be eliminated by purifying the formic acid using a procedure we have developed [17-18] and/or by occasionally pulsing the anode to $1 \mathrm{~V}$ with respect to RHE to remove chemisorbed species formed from impurities in the formic acid feed.

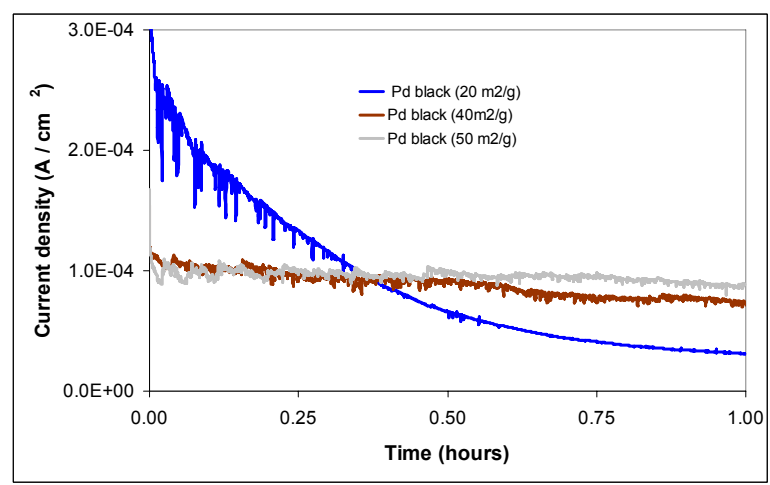

Figure 4 Chronoamperometric data taken during oxidation of formic acid in a solution of $5 \mathrm{M}$ formic acid and $0.1 \mathrm{~N} \mathrm{H}_{2} \mathrm{SO}_{4}$ at $21{ }^{\circ} \mathrm{C}$ at $0.3 \mathrm{~V}$ with respect to RHE formic acid and 0,1 $\mathrm{H}_{2} \mathrm{SO}_{4}$ at $21{ }^{\circ} \mathrm{C}$. Palladium catalysts with 20 $\mathrm{m}^{2} / \mathrm{gm}$ show high initial activity but quickly poison. $\quad 40-50 \mathrm{~m}^{2} / \mathrm{gm}$ show lower initial activity but the activity is stable[10]. 


\subsection{Unexpected ligand effects}

Given our results above we also did a screening study to see if we could further enhance the activity by supporting the palladium particles on a conductive support that we expected to further shift the binding energy.

Figure 5 shows some of the results. In these experiments we grew a thin layer of metal oxide on top of a metal foil, deposited 0.6-1 monolayers of palladium onto the foil via spontaneous deposition or electrodeposition, and then used chronoamperometry to measure the catalytic activity. The results show that one can enhance the rate of formic acid electrooxidation by an additional factor of 20 by depositing the palladium on a vanadia support, even though vanadia is completely inactive for the reaction and vanadia is also inactive for $\mathrm{CO}$ oxidation in an electrochemical cell. High activity is seen even when there are 2 monolayers of Pd on the surface. Thus it appears that there is an interesting ligand effect that needs to be explored.

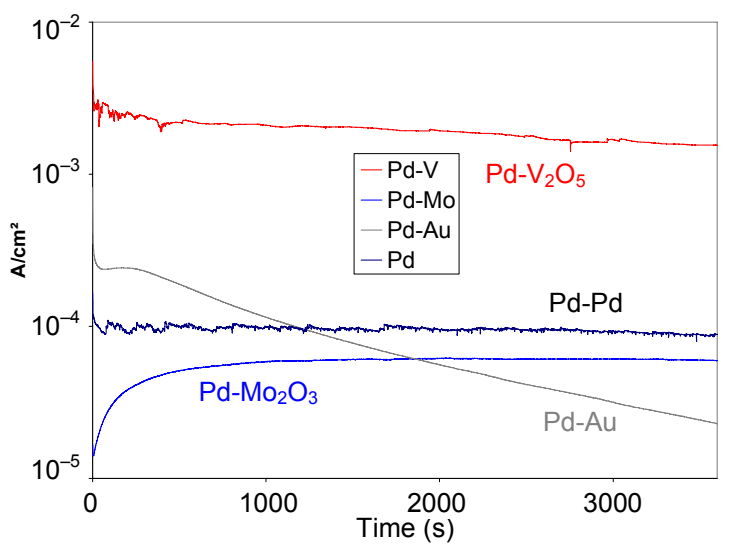

Figure 5 Chronoamperometric data taken at $0.3 \mathrm{~V}$ with respect to RHE during oxidation of formic acid in a solution containing $5 \mathrm{M}$ formic acid and $0.1 \mathrm{M}$ $\mathrm{H}_{2} \mathrm{SO}_{4}$ at $21{ }^{\circ} \mathrm{C}$. The support exerts dramatic effects on the activity of the monolayer-level Pd metal, with the $\mathrm{Pd}-\mathrm{V}_{2} \mathrm{O}_{5}$ catalyst exhibiting highest activity. [8]

\subsection{Additional reaction pathways}

We also noticed that the reaction pathway for formic acid electrooxidation is not as reported previously. In the previous literature, people have said [19-23] that formic acid electrooxidation occurs via two reaction pathways: a "direct" pathway

$\mathrm{HCOOH} \rightarrow ? ? \rightarrow \mathrm{CO}_{2}+2 \mathrm{H}^{+}+2 \mathrm{e}^{-}$

And a pathway involving a $\mathrm{CO}$ intermediate

$\mathrm{HCOOH} \rightarrow \mathrm{CO}+\mathrm{H}_{2} \mathrm{O} \rightarrow \mathrm{CO}_{2}+2 \mathrm{H}^{+}+2 \mathrm{e}^{-}$

We have observed $\mathrm{H}_{2}$ and formic anhydride formation during the reaction. Neither are formed in reactions 1 and 2 . Therefore we believe that there are at least two other reaction pathways:

$\mathrm{HCOOH} \rightarrow ? ? \rightarrow \mathrm{CO}_{2}+\mathrm{H}_{2}$

$2 \mathrm{HCOOH} \rightarrow ? ? \rightarrow \mathrm{HCOOCOH}+\mathrm{H}_{2} \mathrm{O}$

\subsection{Applications in real devices}

We have also verified that our enhanced activities seen in the electrochemical experiments carry over to real fuel cell conditions. Figure 6 compares the IV characteristics of our catalysts to commercial $\mathrm{Pt} / \mathrm{Ru}$. We observe 100 times as much current in the commercially useful range (i.e. 0.6 to $0.8 \mathrm{~V}$. This allowed us to exceed the DOE targets for power density and anode catalyst cost in portable fuel cells. Clearly, the new catalysts are an important advance.

\subsection{Anion and Concentration effects}

Finally, we have characterized some unexpected anion and concentration effects. Generally we find that $\mathrm{H}_{2} \mathrm{SO}_{4}$ enhances the rate of reaction as shown in Figure 7. Such enhancement was also reported by Swamy et al. $[24,25]$. We also find that the rate of formic acid oxidation is independent of concentration, at concentrations between 3 and $10 \mathrm{M}$, and then falls at high formic acid concentrations as shown in Figure 8. Such kinetics have not been reported previously. 


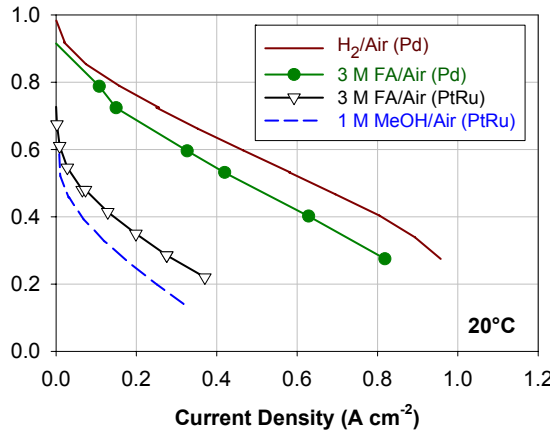

Figure 6 A comparison of the IV characteristics of a formic acid fuel cell with $\mathrm{Pt} / \mathrm{Ru}$ and $\mathrm{Pd}$ catalysts[12]. Notice the large differences in current. The formic acid fuel cell is only slightly better than a methanol fuel cell when a commercial $\mathrm{Pt} / \mathrm{Ru}$ is used. However, the current is 100 times larger when the new catalysts are used.

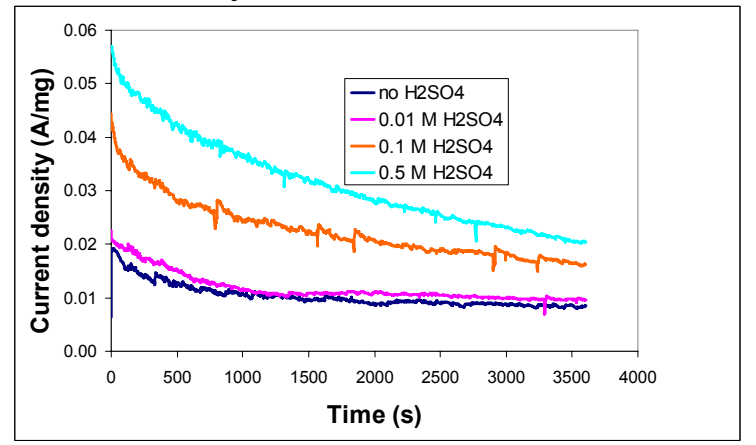

Figure 7 Chronoamperometric data taken during oxidation of formic acid in a solution of $5 \mathrm{M}$ formic acid and varying amounts of $\mathrm{H}_{2} \mathrm{SO}_{4}$ at $21{ }^{\circ} \mathrm{C}$. Notice that the $\mathrm{H}_{2} \mathrm{SO}_{4}$ enhances the rate.

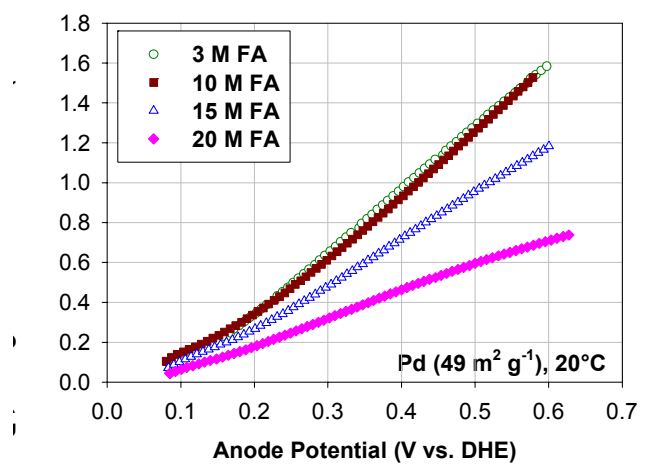

Figure 8 Anode polarization of the catalysts measured as a function of the formic acid concentration[12] at $20{ }^{\circ} \mathrm{C}$. Notice that the rate decreases at high formic acid concentrations.
Table 2 The position of the Pt $4 \mathrm{f}$ XPS peak for $\mathrm{Ru} / \mathrm{Pt}$ 1:1 alloy, Pt decorated $\mathrm{Ru}$ nanoparticles and Pt black.

\begin{tabular}{|c|c|c|}
\hline Compound & $\begin{array}{l}\text { Pt 4f } \\
\text { peak BE } \\
\text { /eV }\end{array}$ & $\begin{array}{l}\text { BE shift vs. } \\
\text { Pt (111)/ } \\
\text { eV }\end{array}$ \\
\hline Pt (11) & 71.10 & 0.00 \\
\hline Pt black & 71.33 & 0.23 \\
\hline $\begin{array}{l}\text { Pt decorated } \mathrm{Ru} \\
\text { nanoparticles }\end{array}$ & 71.47 & 0.37 \\
\hline $\mathrm{Ru} / \mathrm{Pt} \mathrm{1:1} \mathrm{alloy}$ & 71.62 & 0.52 \\
\hline
\end{tabular}

\subsection{XPS characterization of the catalysts}

We have also used XPS to try to understand the difference between the reactivity of (bulk) single crystals and of nanoparticle electrodes for both methanol and formic acid oxidation, and to begin correlating the rate data to binding energy of electrodes of various particle size [26-30]. We have already taken some initial data on ruthenium nanoparticles enhanced by platinum and palladium nanoparticles, respectively to see if the idea has promise. To carry out this project, we developed a new method of immobilization of catalytic metal/alloy nanoparticles on an inert surface (of gold) for the noninvasive transfer from an electrochemical cell to ultrahigh vacuum (UHV) for X-ray photoemission spectroscopy (XPS) measurements. Several $\mathrm{Ru} / \mathrm{Pt}$ nanoparticle catalyst samples were examined: (i) the $\mathrm{Pt}$ decorated $\mathrm{Ru}$ nanoparticles prepared from $\mathrm{Ru}$ black onto which Pt was spontaneously deposited, (ii) the commercial $\mathrm{Ru} / \mathrm{Pt}$ 1:1 alloy nanoparticles and (iii) pure $\mathrm{Pt}$ and $\mathrm{Ru}$ nanoparticle samples (Pt and $\mathrm{Ru}$ blacks). XPS Pt $4 f$ spectra, measured from the decorated and alloy $\mathrm{Ru} / \mathrm{Pt}$ nanoparticle samples show that the $\mathrm{Pt} 4 f \mathrm{BE}$ in the $\mathrm{Ru} / \mathrm{Pt} 1: 1$ alloy nanoparticles is higher by $0.52 \mathrm{eV}$ when compared to that of pure Pt (111) (and $+0.37 \mathrm{eV}$ for the Pt decorated Ru nanoparticles, see Table 2)). Additionally, the $\mathrm{BE}$ for pure platinum and ruthenium blacks is 
shifted toward more positive BE value $(0.23$ and $0.15 \mathrm{eV}$, respectively) when compared to the single crystal BE benchmark. Notably, the $\mathrm{Ru} \mathrm{BE}$ data show a smaller shift with an opposite trend. There is clearly a charge transfer from $\mathrm{Pt}$ to $\mathrm{Ru}$ due to $\mathrm{Pt}$ and $\mathrm{Ru}$ atoms intermixing, confirming previous NMR studies reported by this laboratory.[9]

These data show that there is large difference in $\mathrm{BE}$ between the bulk Pt and $\mathrm{Ru}$ samples and the nanoparticle samples. Rodriguez and Goodman demonstrated [26] a correlation between the $\mathrm{CO}$ adsorption energy on bimetallic surfaces to the BE shift due to the metal intermixing. The Hammer-Norskov model provides the state-of-the-art rationale for this behavior, namely, changes in the adsorbate chemisorption energies scale directly with the changes in the metal center of the d-band. In our work, the most active sample for methanol oxidation is the $\mathrm{Ru} / \mathrm{Pt}$ 1:1 alloy that shows the highest BE Pt $\mathbf{4} \boldsymbol{f}$ shift (vs. Pt(111), the pure Pt black shows the smallest shift, while the $\mathrm{Pt}$ decorated $\mathrm{Ru}$ nanoparticles are in between (Figure 9).

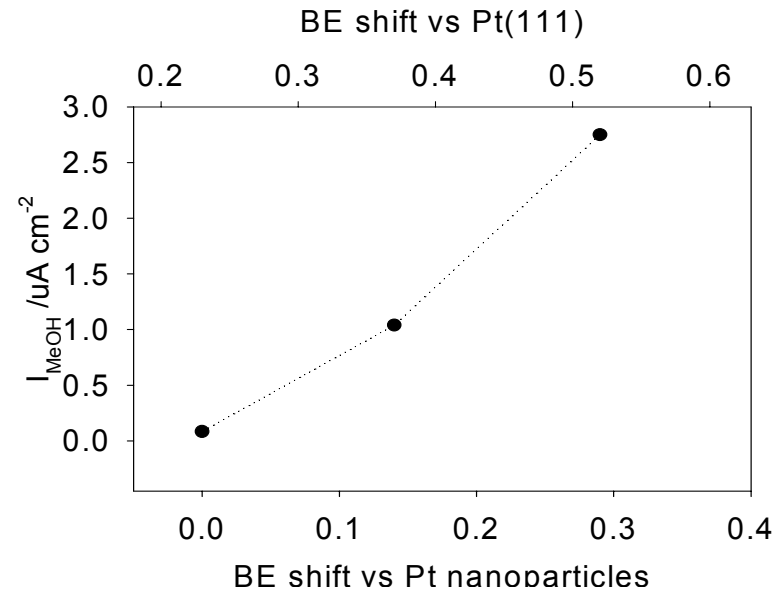

Figure 9 Methanol oxidation currents vs. BE shift for different nanoparticle catalysts: from left to right: Pt black, Pt decorated $\mathrm{Ru}$ and $\mathrm{Ru} / \mathrm{Pt}$ 1:1 alloy nanoparticles.
Table 3 XPS spectra of Pd 3d core levels for a $\mathrm{Pd}$ nanoparticle sample: (A) as received (partially oxidized), (B) completely reduced, and fpr clean $\operatorname{Pd}(111)(\mathrm{C})$.

\begin{tabular}{|l|l|l|}
\hline $\begin{array}{l}\text { Binding Energy } \\
(\text { Ev })\end{array}$ & $\operatorname{Pd}(0)$ & $\begin{array}{l}\text { BE } \\
\text { Shift } \\
\text { vs. } \\
\mathrm{Pd}(111)\end{array}$ \\
\hline C: $\operatorname{Pd}(111)$ & 335.10 & 0.00 \\
\hline B: reduced & 335.31 & 0.21 \\
\hline A: received & 335.33 & 0.23 \\
\hline
\end{tabular}

XPS data of the Pd $3 d$ core levels of Pd nanoparticles immobilized on $\mathrm{Au}$ disk and of Pd (111) are summarized in Table 3. XPS data of the Pd $3 \mathrm{~d}$ core level were obtained for the as-received and oxidized $\mathrm{Pd}$ nanoparticles sample, directly after immobilization on the $\mathrm{Au}$ disk surface. The peak at $335.3 \mathrm{eV}$ is assigned to metallic Pd. After electrochemical reduction only metallic $\mathrm{Pd}$ was detected. The $\mathrm{Pd} 3 \mathrm{~d}_{5 / 2}$ peak at $335.1 \mathrm{eV}$ was then obtained from a clean Pd (111) surface. Thus (Table 3), the binding energy in $\mathrm{Pd}$ nanoparticles is shifted by $+0.2 \mathrm{eV}$ compared to the BE in the bulk of Pd (in the Pd single crystal). Notably, the most active sample for formic acid oxidation is the $\mathrm{Pd}$ nanoparticle sample (Figure 4) that (again) shows the highest BE for Pd $3 \boldsymbol{d}$. We are therefore beginning to establish the trend between particle size, binding energy and the reactivity that will be further explored in this project.

\subsection{Publications Supported by Department of Energy grant DE- FG02-99ER14993 since 2002}

The description above gave some of the highlights of our work. We have 31 publications as outlined below.

\subsubsection{Journal Articles}

1 K.-L. Chu, M. A. Shannon, and R. I. Masel, "Improved Miniature Direct Formic Acid Fuel Cells Based on Nanoporous Silicon Membranes for Portable Power Generation," J. Electrochem Soc., 153(8), A1554-A1561, 
2006.

2 W. P. Zhou, A. Lewera, P. S. Bagus, R. Larsen, R. I. Masel, A. Wieckowski, "Size Effects in Electronic and Catalytic Properties of Unsupported Palladium Nanoparticles in Electrooxidation of Formic Acid," Journal of Physical Chemistry B, 110 (27), 13393-13398, 2006 .

3 S. Ha, Z. Dunbar, and R. I. Masel, "Characterization of a High Performing Passive Direct Formic Acid Fuel Cell," Journal of Power Sources, 158, 129-136, 2006.

4 P. K. Babu, H.-S. Kim, S. T. Kuk, J. Ho Chung, E. Oldfield, E. S. Smotkin (UPR) and A. Wieckowski, "Activation of Nanoparticle $\mathrm{Pt} / \mathrm{Ru}$ Fuel Cell Catalysts by Heat Treatment: A ${ }^{195} \mathrm{Pt}$ NMR and Electrochemical Study", J. Phys. Chem. B., submitted.

5 A. Lewera, W. P. Zhou, C. Vericat, J.H. Chung, R. Haasch, A. Wieckowski and P. S. Bagus "X-ray Photoemission Spectroscopy and Reactivity Measurements of $\mathrm{Ru} / \mathrm{Pt}$ Nanoparticles Supported on a Gold Disk", Analytical Chemistry, in preparation.

6 M. S. McGovern, P. Waszczuk and A. Wieckowski, "Stability of Carbon Monoxide Adsorbed on Nanoparticle $\mathrm{Pt}$ and $\mathrm{Pt} / \mathrm{Ru}$ Electrodes in Sulfuric Acid Media", Electrochimica Acta, in press.

7 R. Larsen, S. Ha, J. Zakzeski and R. I. Masel, "Unusually Active Palladium Based Catalysts for the Electrooxidation of Formic Acid," Journal Power Sources, 157(1):78-84, 2006.

8 179. S. Ha, R. Larsen and R. I. Masel, "Performance Characterization of $\mathrm{Pd} / \mathrm{C}$ Nanocatalyst for Direct Formic Acid Fuel Cells," J. Power Sources, 144, 28-34, 2005.

9 174. R. Larsen, J. Zakzeski, Y.Zhu, and R. I. Masel, "Unexpected Activity of Palladium on Vanadia Catalysts for Formic Acid Electrooxidation," Electrochemical and Solid-State Letters, 8(6) A291-293, 2005.
10 Y. Zhu, Z. Khan and R. I. Masel, "Performance characterization of $\mathrm{Pd}$ nanocatalyst for direct formic acid fuel cells", J. Power Sources, 139 (2005) 15.

11 S. Ha, R. Larsen, Y. Zhu, and R. I. Masel, "Direct formic acid fuel cells with 600 $\mathrm{mA} / \mathrm{cm} 2$ at $0.4 \mathrm{~V}$ and $220 \mathrm{C}$ ", Fuel Cells, 4(2004) 337-343.

12 J. Spendelow, G. Q. Lu, P. J. A. Kenis and A. Wieckowski, "Electrooxidation of Adsorbed $\mathrm{CO}$ on $\mathrm{Pt}(111) / \mathrm{Ru}$ in Alkaline Media: Comparison with Results from Acidic Media", J. Electroanal. Chem., 568, 215-224 (2004).

13 R. Larson and R. I. Masel, "Kinetic study of $\mathrm{CO}$ tolerance during electrooxidation of formic acid on spontaneously deposited $\mathrm{Pt} / \mathrm{Pd}$ and $\mathrm{Pt} / \mathrm{Ru}$ nanoparticles", Electrochemical and Solid State Letters, 7, A148-A150, 2004.

14 Y. Zhu, S. Ha, and R. I. Masel, "High Power Density Direct Formic Acid Fuel Cells", J. Power Sources, 130, 1-2, 8-14, 2004.

15 F. Thomas and R. I. Masel, "Formic Acid Decomposition on Palladium-Coated Pt(110)", Surface Science, 573(2004) 169-175.

16 B. Adams, S. Ha, Y. Zhu, R. Larsen, M. Shannon, A. Wieckowski, and R. I. Masel, "Formic Acid Fuel Cells: New Possibilities For Portable Power", Proceedings Power Sources, 41, 428-431, 2004.

17 S. Ha, B. Adams, and R. I. Masel, "A Miniature Air Breathing Direct Formic Acid Fuel Cell", J. Power Sources, 128, 2, 119-124, 2004.

18 M. Zhao, C. Rice, R. I. Masel, P. Waszczuk, and A. Wieckowski, "Kinetic Study of Electrooxidation of Formic Acid on Spontaneously-Deposited Pt/Pd Nanoparticles. CO Tolerant Fuel Cell Chemistry", J. Electrochem. Soc., 151, A131-A136 (2004).

19 P. K. Babu, H.-S. Kim, E. Oldfield and A. Wieckowski, "Electronic Alterations Caused by Ruthenium in $\mathrm{Pt} / \mathrm{Ru}$ Alloy Nanoparticles as 
Revealed by Electrochemical NMR", J. Phys. Chem. 107, 7595-7600 (2003).

20 C. Rice, S. Ha, R. I. Masel, A. Wieckowski, J. Power Sources, "Catalysts for Direct Formic Acid Fuel Cells", 115, 229-235 (2003).

21 M. S. McGovern, E. C. Garnett, C. Rice, R. I. Masel, A. Wieckowski, "Effects of Nafion as a Binding Agent for Unsupported Nanoparticle Catalysts", J. Power Sources, 115, 35-39 (2003).

22 S. Ha, C. A. Rice, R. I. Masel, A. Wieckowski, "Methanol conditioning for improved performance of formic acid fuel cells", J. Power Sources, 112, 655-659 (2002).

23 C. Rice, S. Ha, R. I. Masel, P. Waszczuk, A. Wieckowski, T. Barnard, "Direct Formic Acid Fuel Cells", J. Power Sources, 111, 8389 (2002).

24 P. Waszczuk, G.-Q. Lu, A. Wieckowski, C. Lu, C. Rice, and R. I. Masel, "UHV and Electrochemical Studies of CO and Methanol Adsorbed at Platinum/Ruthenium Surfaces, and Reference to Fuel Cell Catalysis", Electrochimica Acta, 47, 3637-3652 (2002).

25 C. Lu, C. Rice, R. I. Masel, P. K. Babu, P. Waszczuk, H.-S. Kim, E. Oldfield, A. Wieckowski, "UHV, Electrochemical NMR and Electrochemical Studies of Platinum/Ruthenium Fuel Cell Catalysts", J. Phys. Chem., B, 106, 9581-9589 (2002).

26 C. Lu, I. C. Lee, R. I Masel, A. Wieckowski and C. Rice, "Correlations between the heat of adsorption and the position of the center of the d-band: Differences between computation and experiment", J. Phys. Chem. B, 106, 30843091 (2002).

27 C. Rice, S. Ha, R. I. Masel, P. Waszczuk and A. Wieckowski, "Characteristics Of Small Formic Acid Fuel Cells", Proceedings 40th Power Sources Conference, 254-258, 2002.

28 P. Waszczuk, T. M. Barnard, C. Rice, R.
I. Masel and A. Wieckowski, "A Nanoparticle Catalyst With Superior Activity for Electrooxidation of Formic Acid", Electrochemistry Communications, 4, 599603, 2002.

29 P. Waszczuk, T. M. Barnard, C. Rice, A. Wieckowski* [addition] and R. I. Masel, "A Nanoparticle Catalyst with Superior Activity for Electrooxidation of Formic Acid," Electrochemistry Communications, 4, 732, 2002.

30 C. Rice, S. Ha, R. I. Masel, P. Waszczuk, A. Wieckowski, "Direct Formic Acid Fuel Cells," J. Power Sources, 111, 83-89, 2002.

31 C. Lu, C. Rice, P. K. Babu, P. Waszczuk, H.S. Kim, E. Oldfield, A. Wieckowski and R. I. Masel, "UHV, Electrochemical NMR and Electrochemical Studies of Platinum/Ruthenium Fuel Cell Catalysts," J. Physical Chemistry, B, 106, 9581-9589, 2002.

32 I. C. Lee and R. I. Masel, "Measurement of the Metal Surface Acidity/Electronegativity of Pt(110)," Catalysis Letters, 83, 43-48, 2002.

\subsubsection{Allowed patents}

33 Masel, R.I. and C.A. Rice, "Solids Supporting Mass Transfer for Fuel Cells and Other Applications and Solutions and Methods for Forming," US Patent US7,108,773, Sept. 2006

34 Masel, R.I., C.A. Rice, P. Waszczuk and A. Wieckowski, "Fuel Cells and Fuel Cells Catalysts," US Patent US7,132,188, Nov, 2006.

35 Masel, R.I., C.A. Rice, P. Waszczuk and A. Wieckowski, "Fuel Cells and Fuel Cells Catalysts," British Patent GB2401987, Mar, 2006.

36 Masel, R.I., C. Rice, P. Waszczuk and A. Wieckowski, "Fuel Cell and Fuel Cell Catalysts," British Patent GB2420219, Oct 2006

37 7. Masel, R.I., Y. Zhu, Z. Kahn, M. Man, "Low contaminant formic acid fuel for direct 
liquid fuel cell," British Patent, GB2424650B, May 2007

38 Masel, R.I., S. Ha, B. Adams, "Organic fuel cells conducting sheets and Fuel Cell Conduction " US patent submitted 10/664,772, US20040115518. Allowed

\subsubsection{Pending Patent applications}

39 Masel, R.I., C. Rice, "Fuel Cell and Fuel Cell Catalysts," US Patent continuation Submitted, 11/303505

40 Masel, R.I., C. Rice, "Fuel Cell and Fuel Cell Catalysts," PCT-Australia Patent Submitted, 2003221669

41 Masel, R.I., C. Rice, "Fuel Cell and Fuel Cell Catalysts," PCT-China Patent Submitted, 03812798.9

42 Masel, R.I., C. Rice, "Fuel Cell and Fuel Cell Catalysts," PCT-Germany Patent Submitted, 10392493.0

43 Masel, R.I., C. Rice, "Fuel Cell and Fuel Cell Catalysts," PCT-Japan Patent Submitted, 2003585217

44 Masel, R.I., C. Rice, "Fuel Cell and Fuel Cell Catalysts," PCT-Korea Patent Submitted, 10-2004-7015790

45 Masel, R.I., R. Larsen, S. Y. Ha, "Formic Acid Fuel Cell and Fuel Cell Catalysts," WO2005/081706.

46 Masel, R.I., Y. Zhu and R.T. Larsen, "Palladium Based Electrocatalysts and Fuel Cells Employing such Catalysts," Application: US2005136309.

47 Masel, R.I., Y. Zhu and R.T. Larsen, "Improved Palladium Based Electrocatalysts and Fuel Cells Employing Such Electrocatalysts," Application: WO, 2005048379, 2005.

48 Masel, R.I., S. Y. Ha and B.A. Adams, "Organic Fuel Cells and Fuel Cell Conduction Sheets," PCT Application: WO2005029609

49 Masel, R.I., S. Ha, B. Adams, "Organic fuel cells conducting sheets" Great Britain patent submitted GB0603857.4

50 Masel, R.I., S. Ha, B. Adams, "Formic Acid Fuel Cells and Catalysts" WO2005081706.

51 Masel, R.I., Y. Zhu, Z. Kahn, M. Man, "Low contaminant formic acid fuel for direct liquid fuel cell," US patent Application 11/079,893 Publication US20060059769

52 Masel, R.I., Y. Zhu, Z. Kahn and M. Man, "Low Contaminant Formic Acid Fuel for Direct Liquid Fuel Cell," Application: WO20060059769

53 Masel, R.I., Y. Zhu, Z. Kahn, M. Man, "Low contaminant formic acid fuel for direct liquid fuel cell," China patent submitted

54 Masel, R.I., Y. Zhu, Z. Kahn, M. Man, "Low contaminant formic acid fuel for direct liquid fuel cell," AU patent submitted AU2008205749

55 Masel, R.I., Y. Zhu, Z. Kahn, M. Man, "Low contaminant formic acid fuel for direct liquid fuel cell," Germany Patent submitted DE102005045042

56 Masel, R.I., Y. Zhu, Z. Kahn, M. Man, "Low contaminant formic acid fuel for direct liquid fuel cell," GB241,913,5

57 Masel, R.I., Y. Zhu, Z. Kahn, M. Man, "Low contaminant formic acid fuel for direct liquid fuel cell," Japan patent submitted JP2005269415

58 Masel, R.I., Y. Zhu, Z. Kahn, M. Man, "Low contaminant formic acid fuel for direct liquid fuel cell," Korea patent submitted

59 R. I. Masel, Robert Larsen, Yimin Zhu, "Palladium-Based Electrocatalysts and Fuel Cells Employing such Electrocatalysts", \# 10/817,361.

\subsubsection{Startup company based on the findings}

A new company, Renew Power/Tekion has been started to build formic acid fuel cells 
using the catalysts discovered in this program. The company already has 50 employees and has received funding from Motorola. 


\section{Literature cited}

1 Fuel Cell Roadmap, ESECS EE-1973, U.S. Department of Energy, February 2003.

2 Proceedings of the Workshop: Fuel Cells for Portable Power, U.S. Department of Energy, January 15-17, 2002.

3 P. Waszczuk, T. M. 'Barnard, C. Rice, R. I. Masel and A. Wieckowski, "A Nanoparticle Catalyst With Superior Activity for Electrooxidation of Formic Acid", Electrochemistry Communications, 4, 599-603, 2002.

4 S.T. Kuk and A. Wieckowski, "Methanol electrooxidation on platinum spontaneously deposited on unsupported and carbon-supported ruthenium nanoparticles", J. of Power Sources, 141, 1-7 (2004).

5 W. Chrzanowski and A. Wieckowski, "Surface Structure Effects in Platinum/Ruthenium Methanol Oxidation Electrocatalysis", Langmuir, 14, 1967 (1998).

6 W. Chrzanowski and A. Wieckowski, "Ultra-Thin Films of Ruthenium on Low Index Platinum Single Crystal Surfaces: An Electrochemical Study", Langmuir, 13, 5974 (1997).

7 Lu, G.Q., A. Crown, A. Wieckowski, "Formic acid decomposition on polycrystalline platinum and palladized platinum electrodes", Journal of Physical Chemistry B, 103. 9700-9711 (1999).

8 C. Rice, S. Ha, R. I. Masel, A. Wieckowski, "Catalysts for Direct Formic Acid Fuel Cells", J. Power Sources, 115, 229-235 (2003).

9 R. Larsen, S. Ha, J. Zakzeski and R. I. Masel, "Unusually active palladium based catalysts for the electrooxidation of formic acid", Submitted.

10 R. I. Masel, Robert Larsen, Yimin Zhu, "Palladium-Based Electrocatalysts and Fuel Cells Employing such Electrocatalysts", US patent application \# 10/817,361.

11 S. Ha, R. Larsen and R. I. Masel, "Performance characterization of $\mathrm{Pd} / \mathrm{C}$ nanocatalysts for direct formic acid fuel cells", J. Power Sources, Accepted.

12 Y. Zhu, Z. Khan and R. I. Masel, "Performance characterization of $\mathrm{Pd}$ nanocatalyst for direct formic acid fuel cells", J. Power Sources, 139 (2005) 15.

13 M. Zhao, C. Rice, R. I. Masel, P. Waszczuk, and A. Wieckowski, "Kinetic Study of Electrooxidation of Formic Acid on Spontaneously-Deposited $\mathrm{Pt} / \mathrm{Pd}$ Nanoparticles. CO Tolerant Fuel Cell Chemistry", J. Electrochem. Soc., 151, A131-A136 (2004).

14 F. Thomas and R. I. Masel, "Formic Acid Decomposition on Palladium-Coated Pt(110)", Surface Science, 573(2004) 169175.

15 R. Larson and R. I. Masel, "Kinetic study of $\mathrm{CO}$ tolerance during electrooxidation of formic acid on spontaneously deposited $\mathrm{Pt} / \mathrm{Pd}$ and $\mathrm{Pt} / \mathrm{Ru}$ nanoparticles", Electrochemical and Solid State Letters, 7, A148-A150, 2004.

16 Capon, A., and R. Parsons, "Oxidation of formic acid on noble metal electrodes ii: comparison of the behavior of pure electrodes", Journal of Electroanalytical Chemistry, 44. 239-254 (1973).

17 S. Ha, R. Larsen, Y. Zhu, and R. I. Masel, "Direct formic acid fuel cells with $600 \mathrm{~mA} / \mathrm{cm} 2$ at $0.4 \mathrm{~V}$ and $220 \mathrm{C}$ ", Fuel Cells, 4(2004) 337-343.

18 R. I. Masel, Y. Zhu, Z. Khan, M. Man, "Fuel composition for fuel cells", US patent application, submitted

19 Jarvi, T. D.; Stuve, E. M. "Fundamental Aspects of Vacuum and Electrocatalytic Reactions of Methanol and Formic Acid on Platinum Surfaces"; Lipkowski, J. and Ross, P. N., Ed.; Wiley-VCH: New York, 1998, pp 
Ch. 3.

20 Markovic, N.; Gaseiger, H.; Ross, P.; Jian, X.; Villegas, I.; Weaver, M. Electrochemica Acta 1995, 40, 91.

21 Parson, R.; VanderNoot, T. J. Electroanal. Chem. 1988, 257, 9.

22 Ross, P. N., "The Science of Electrocatalysis on Bimetallic Surfaces"; Lipkowski, J. and Ross, P. N., Ed.; WileyVCH: New York, 1998, pp 63.

23 C. Lu, C. Rice, R. I. Masel, P. K. Babu, P. Waszczuk, H.-S. Kim, E. Oldfield, A. Wieckowski, "UHV, Electrochemical NMR and Electrochemical Studies of Platinum/Ruthenium Fuel Cell Catalysts", J. Phys. Chem., B, 106, 9581-9589 (2002).

24 Swamy BEK. Maye J. Vannoy C. Schell M., "Improvements in the efficiency of the oxidation of formic acid obtained by increasing the overall anion adsorption strength", Journal of Physical Chemistry B. 108:16488-16494, 2004

25 Swamy BEK. Vannoy C. Maye J. Schell M., "Increases in reaction rates achieved by replacing anions in the electrolyte with more inhibiting ones", Electrochemistry Communications. 6:1032-1036, 2004

26 M. Zhao, C. Rice, R. I. Masel, P. Waszczuk, and A. Wieckowski, "Kinetic Study of Electrooxidation of Formic Acid on Spontaneously-Deposited $\mathrm{Pt} / \mathrm{Pd}$ Nanoparticles. CO Tolerant Fuel Cell Chemistry", J. Electrochem. Soc., 151, A131-A136 (2004).

27 J. A. Rodriguez and D. W. Goodman, "The Nature of the Metal-Metal Bond in Bimetallic Surfaces", Science, 257, 897-903 (1992).

28 M.G. Mason, "Electronic structure of supported small metal clusters", Physical Review B, 27 (1983) 748-762.

29 P. S. Bagus, F. Illas, G. Pacchioni, F. Parmigiani, "Mechanisms responsible for chemical schifts of core-level binding energies and their relationship to chemical bonding”, Journal of Electron Spectroscopy and Related Phenomena, 100 (1999) 215236.

30 A. Lewera, W. P. Zhou, C. Vericat, J.H. Chung, R. Haasch, A. Wieckowski and P. S. Bagus, "X-ray Photoemission Spectroscopy and Reactivity Measurements of $\mathrm{Ru} / \mathrm{Pt}$ Nanoparticles Supported on a Gold Disk", Analytical Chemistry, in preparation.

31 S. Strbac, C. M. Johnston, G. Q. Lu, A. Crown and A. Wieckowski, "In situ STM Study of Nanosized $\mathrm{Ru}$ and Os Islands Spontaneously Deposited on $\operatorname{Pt}(111)$ and Au(111) Electrodes", Surface Science, 573, 80 - 99 (2004).

32 S. Strbac, O. M. Magnussen, R.J. Behm, A. Crown and A. Wieckowski, "In situ STM Imaging of Spontaneously Deposited Ruthenium on $\mathrm{Au}(111)$ ", Surface Science, 517, 207-218 (2002).

33 A. Crown, C. Johnston and A. Wieckowski, "Growth of Ruthenium Islands on $\mathrm{Pt}(\mathrm{hkl})$ Electrodes Obtained via Repetitive Spontaneous Deposition", Surface Science, 506, L268-L274 (2002).

34 E. Herrero-Rodriguez, J. M. Feliu and A. Wieckowski, "STM Images of Ruthenium Submonolayers Spontaneously Deposited on a Pt(111) Electrode", Langmuir, 15, 4944 (1999).

35 M. Gamboa-Aldeco, K. Franaszczuk and A. Wieckowski, "Radiotracer Study of Electrode Surfaces", in Handbook of Surface Imaging and Visualization, A. T. Hubbard, ed., CRC Press, NY, 1995, p. 635.

36 M. S. McGovern, P. Waszczuk and A. Wieckowski, "Stability of Carbon Monoxide Adsorbed on Nanoparticle $\mathrm{Pt}$ and $\mathrm{Pt} / \mathrm{Ru}$ Electrodes in Sulfuric Acid Media", Electrochimica Acta, in press.

37 P. K. Babu, H.-S. Kim, E. Oldfield and 
A. Wieckowski, "Electronic Alterations Caused by Ruthenium in $\mathrm{Pt} / \mathrm{Ru}$ Alloy Nanoparticles as Revealed by Electrochemical NMR", J. Phys. Chem. 107, 7595-7600 (2003).

38 P. K. Babu, H. S. Kim, J. H. Chung, E. Oldfield, A. Wieckowski, "Bonding and Motional Aspects of CO Adsorbed on the Surface of Pt Nanoparticles Decorated with Pd", J. Phys. Chem. B, 108, 20228-20232 (2004).

39 P. K. Babu, H.-S. Kim, S. T. Kuk, J. Ho Chung, E. Oldfield, E. S. Smotkin (UPR) and A. Wieckowski, "Activation of
Nanoparticle Pt/Ru Fuel Cell Catalysts by Heat Treatment: A ${ }^{195} \mathrm{Pt}$ NMR and Electrochemical Study", J. Phys. Chem. B., submitted.

40 Y. Y. Tong, H. S. Kim, P. K. Babu, P. Waszczuk, A. Wieckowski, E. Oldfield, "An NMR Investigation of $\mathrm{CO}$ Tolerance in a $\mathrm{Pt} / \mathrm{Ru}$ Fuel Cell Catalyst", J. Am. Chem. Soc., 124, 468-473 (2002).

41 Y. Y. Tong, T. Yonezawa, N. Toshima and J. J. Van der Klink, "Pt-195 NMR of Polymer-Protected $\mathrm{Pt} / \mathrm{Pd} \quad$ Bimetallic Catalysts", J. Phys. Chem. 100, 730-733 (1996).' 